\title{
PENGARUH KEBIJAKAN DEVIDEN TERHADAP NILAI PERUSAHAAN MANUFAKTUR SEKTOR FOOD AND BEVERAGES
}

\author{
Sulistyowati \\ Institut Islam Mamba'ul 'Ulum (IIM) Surakarta \\ suliscan65@gmail.com
}

\begin{abstract}
The prosperity of shareholders can usually be seen from the high value of the company. This means that maximizing shareholder prosperity can be done by maximizing the value of the company. The higher the value of the company, the greater the prosperity that will be received by the shareholders. In the era of globalization, manufacturing companies in the food and beverages sector in Indonesia are trying to produce highquality goods at low cost in order to increase competitiveness in the domestic market as well as in the global market. Most manufacturing companies in the food and beverages sector are also companies that rely on capital from investors in carrying out their production activities so it is very important for companies to maintain their liquidity health. This type of research is quantitative descriptive research with a case study method. Based on the discussion it can be concluded that dividend policy has a positive and significant effect on the value of manufacturing companies in the food and beverages sector. This is evidenced by the results of the t test value yaituthitung 3.395 and $p$ value $0.001<0.05$
\end{abstract}

Keywords: Dividend policy, company value

\section{Pendahuluan}

Setiap perusahaan yang didirikan memiliki tujuan untuk memaksimalkan kemakmuran pemegang saham.Kemakmuran para pemegang saham biasanya dapat dilihat dari tingginya nilai perusahaan. Hal ini berarti memaksimalkan kemakmuran pemegang saham dapat dilakukan dengan cara memaksimalkan nilai perusahaan. Semakin tinggi nilai perusahaan maka akan semakin besar kemakmuran yang akan diterima oleh pemegang saham. Perusahaan sektor makanan dan minuman (food and beverages) merupakan salah satu sektor usaha yang terusmengalami pertumbuhan. Seiring dengan meningkatnya pertumbuhan jumlah penduduk di Indonesia, volume kebutuhan terhadap makanan dan minuman pun terus meningkat pula. Kecenderungan masyarakat Indonesia untuk 
menikmati makanan ini menyebabkan banyak bermunculan perusahaan- perusahaan baru di bidang makanan dan minuman karena mereka menganggap sektor industri food and beverages memilik prospek yang menguntungkan baik di masa sekarang maupun yang akan datang.

Dalam era globalisasi, perusahaan manufaktur sektor food and beverages diIndonesia berusaha untuk memproduksi barang yang berkualitas tinggi dengan biaya rendah agar dapat meningkatkan daya saing di pasar domestik maupun di pasar global.Sebagian besar perusahaan manufaktur sektor food and beverages juga merupakan perusahaan yang mengandalkan modal dari investor dalam melakukan kegiatan produksinya sehingga sangat penting bagi perusahaan untuk menjaga kesehatan likuiditasnya. Untuk dapat tetap bertahan dan bersaing, perusahaan membutuhkan dana yang cukup. Salah satu cara yang dapat digunakanperusahaan untuk memenuhi kebutuhan dananya yaitu dengan menarik investor melalui sahamnya di pasar modal.

Perusahaan manufaktur sektor food and beverages merupakan salah satu yang termasuk ke dalam sektor industri barang konsumsi. Perusahaan manufaktursektor food and beverages dipilih sebagai unit analisis dalam penelitian ini karena perusahaan ini memegang peranan penting dalam memenuhi kebutuhan konsumen. Perusahaan manufaktur sektor food and beverages juga merupakan perusahaan yang terstruktur, yaitu produk yang dihasilkan harus terdaftar di Badan Pengawasan Obat-obatan dan Makanan (BPOM).Dian Anggraeni (2010) mengemukakan produk perusahaan makanan dan minuman merupakan salah satu komoditas ekspor unggulan di sektor non-migas. Kebutuhan masyarakat akan produk makanan dan minuman akan selalu ada karena merupakan salah satu kebutuhan pokok. Didasarkan pada kenyataan tersebut, perusahaan makanan dan minuman dianggap akan terus survive.

Perusahaan Food \& Beverages dipilih karena memegang peranan penting dalam memenuhi kebutuhan konsumen. Kebutuhan masyarakat akan produk makanan dan minuman akan selalu ada karena merupakan salah satu kebutuhan pokok. Didasarkan pada kenyataan tersebut, perusahaan makanan dan minuman dianggap akan terus survive. Industri makanan dan minuman adalah industri yang 
perkembangannya baik, pertumbuhan yang positif, sangat cepat dan akan selalu ada karena merupakan salah satu kebutuhan pokok. Industri makanan, minuman, masih menjadi cabang yang memberikan kontribusi terbesar terhadap pertumbuhan industri nasional. Namun, meskipun industri makanan dan minuman merupakan salah satu kontributor terbesar dalam pertumbuhan, masih banyak faktor termasuk kebijakan pemerintah yang masih belum sepenuhnya mendukung perkembangan industri makanan dan minuman itu sendiri. Sementara ancamandari produk impor terus bertambah sejalan dengan integrasi perekonomian Indonesia dengan perekonomian regional dan global.

Pertumbuhan yang positif dari perusahaan food and beverages tersebut dapat mempengaruhi investor untuk menanamkan sahamnya pada perusahaan tersebut. Salah satu pertimbangan investor dalam melakukan investasi adalah nilai perusahaan. Nilai perusahaan merupakan suatu hal yang penting bagi seorang manajer maupun bagi seorang investor. Bagi seorang manajer nilai perusahaan merupakan suatu tolak ukur atas prestasi kerja yang telah dicapainya.Jika seorang manajer mampu untuk meningkatkan nilai perusahaan maka manajer tersebut telah menunjukkan kinerja baik bagi perusahaan.Selain itu, secara tidak langsung manajer ini telah mampu untuk meningkatkan kemakmuran bagi pemegang saham yang merupakan tujuan perusahaan.Sedangkan bagi investor peningkatan nilai perusahaan merupakan suatu persepsi yang baik terhadap perusahaan. Dan jika seorang investor sudah memiliki suatu pandangan yang baik terhadap perusahaan maka investor tersebut akan tertarik untuk berinvestasi sehingga hal ini akan membuat harga saham perusahaan mengalami peningkatan.

Kegiatan investasi yang dilakukan oleh perusahaan diharapkan memberikanlaba yang optimal yang digunakan kembali untuk kegiatan investasi atau dibagikan kepada pemegang saham dalam bentuk dividen.Kebijakan dividen merupakan keputusan mengenai pembagian laba atau menahannya guna diinvestasikan kembali di dalam perusahaan. Dividen dapat digunakan untuk mengurangi agency problem dalam perusahaan (Shubiri et al., 2012). Kebijakan dividen akan berdampak terhadap besarnya laba ditahan perusahaan yang 
merupakan sumber pendanaan internal perusahaan yang akan digunakan untuk mengembangkan perusahaan di masa yang akan datang (Uwigbe et al., 2012).

Perusahaan membagikan dividen apabila perusahaan memiliki kelebihan dana yang diperoleh dari operasi perusahaan (laba setelah pajak+penyusutan). Jumlah maksimum dana yang dibagikan sebagai dividen diukur dengan menggunakan laba bersih setelah pajak. Semakin tinggi pembayaran dividen kas suatu perusahaan, akan menimbulkan sinyal positif bagi para pemegang saham. Sinyal tersebut mengindikasikan bahwa keuntungan perusahaan semakin meningkat.Meningkatnya laba perusahaan mengakibatkan meningkatnya harga saham perusahaan. Peningkatan harga saham perusahaan akan berdampak terhadap peningkatan nilai perusahaan.

Kebijakan dividen tetap menjadi salah satu kebijakan keuangan yang palingpenting tidak hanya dari sudut pandang perusahaan, tetapi juga dari sudut pandang pemegang saham, konsumen, karyawan, badan pengawas dan Pemerintah (Uwuigbe et al., 2012). Pembayaran dividen yang tinggi kepada para pemegang saham mencerminkan harga pasar saham meningkat, sehingga nilai perusahaan juga akan meningkat. Penelitian yang dilakukan oleh Fenandar dan Raharja (2012) pada perusahaan manufaktur, Efni dkk. (2011) pada perusahaan real estate dan properties, Wongso (2012) dan Sudarman (2010) melakukan penelitian pada perusahaan yang tergabung dalam LQ 45 di BEI, serta Lestari dkk. (2012) melakukan penelitian pada perusahaan manufaktur, menghasilkan kesimpulan yang berbeda-beda mengenai pengaruh keputusan investasi, kebijakan dividen, serta keputusan pendanaan terhadap nilai perusahaan. Beberapa peneliti menemukan bahwa keputusan investasi, kebijakan dividen, serta keputusan pendanaan berpengaruh positif terhadap nilai perusahaan, sedangkan beberapa peneliti lainnya menemukan bahwa keputusan pendanaan tidak memiliki dampak yang signifikan terhadap nilai perusahaan dan kebijakan dividen berpengaruh negatif terhadap nilai perusahaan, hal tersebut menunjukkan bahwa adanya kesenjangan dari hasil penelitian-penelitian sebelumnya (research gap) yang menjadi salah satu sumber masalah dalam penelitian ini. 


\section{Kerangka Teortitik Dan Hipotesis}

\section{Pengaruh keputusan investasi terhadap nilai perusahaan}

Nilai perusahaan merupakan nilai kini dari pendapatan mendatang, nilai pasar kapital yang bergantung pada kemampuan menghasilkan arus kas serta karakteristik operasional dan keuangan dari perusahaan yang diambil alih. Nilai perusahaan juga dapat mempengaruhi persepsi investor mengenai perusahaan karena nilai perusahaan dianggap mencerminkan kinerja perusahaan (Lestari dkk, 2012). Nilai perusahaan yang semakin tinggi, akan berdampak terhadap peningkatan kemakmuran yang dicapai para pemegang saham. Investasi merupakan tindakan untuk menanamkan dana yang dimiliki saat ini ke dalam bentuk aktiva lancar maupun aktiva tetap dengan harapan untuk memperoleh keuntungan di masa yang akan datang (Salim dan Moeljadi, 2001: 110). Kegiatan investasi yang dilakukan oleh perusahaan diharapkan memberikan laba yang optimal yang digunakan kembali untuk kegiatan investasi atau dibagikan kepada pemegang saham dalam bentuk dividen.

Keputusan investasi merupakan keputusan yang dikeluarkan perusahaan terkait dengan kegiatan perusahaan untuk melepaskan dana pada saat sekarang dengan harapan untuk menghasilkan arus dana masa mendatang dengan jumlah yang lebih besar dari yang dilepaskan pada saat investasi awal, sehingga harapan perusahaan untuk selalu tumbuh dan berkembang akan semakin jelas dan terencan (Setiani, 2012: 3). Apabila perusahaan mampu menciptakan keputusan investasi yang tepat maka aset perusahaan akan menghasilkan kinerja yang optimal sehingga memberikan sinyal positif bagi investor yang nantinya akan meningkatkan harga saham dan menaikkan nilai perusahaan. Keputusan investasi mempunyai dimensi waktu jangka panjang, sehingga keputusan yang akan diambil harus dipertimbangkan dengan baik, karena mempunyai konsekuensi berjangka panjang pula. Keputusan investasi sering disebut sebagai capital budgeting yakni keseluruhan proses perencanaan dan pengambilan keputusan mengenai pengeluaran dana yang jangka waktu kembalinya dana tersebut melebihi satu tahun (Sutrisno, 2007: 121). Keputusan investasi dalam penelitian ini dihitung menggunakan Price Earning Ratio. Price Earning Ratio merupakan 
salah satu indikator yang sering digunakan oleh analis sekuritas untuk menilai harga suatu saham yang diperdagangkan di pasar modal. Rasio ini menunjukkan seberapa banyak investor bersedia membayar per dolar laba yang dilaporkan (Brigham dan Houston, 2006: 92).

Keputusan investasi merupakan ketetapan yang dibuat oleh pihak perusahaan dalam membelanjakan dana yang dimilikinya dalam bentuk aset tertentu dengan harapan mendapatkan keuntungan di masa yang akan datang (Nahdiroh, 2013). Subekti dalam Rhakimsyah dan Gunawan (2011) menyatakan bahwa perusahaan adalah kombinasi antara nilai aktiva riil (asset in place) dengan pilihan investasi di masa yang akan datang. Hasil penelitian yang dilakukan oleh Rizqia et al. (2013), Honarbakhsh et al. (2013), serta Wijaya, dkk (2010) adalah keputusan investasi memiliki pengaruh positif terhadap nilai perusahaan. Berdasarkan tinjauan teori dan penelitian terdahulu tersebut maka dapat dirumuskan hipotesis sebagai berikut: H1: Keputusan investasi berpengaruh positif dan signifikan terhadap nilai perusahaan manufaktur sektor food and beverages di Bursa Efek Indonesia periode 2011-2014.

\section{Pengaruh keputusan pendanaan terhadap nilai perusahaan}

Pendanaan adalah faktor yang sangat penting dalam menjalankan operasi perusahaan. Salah satu keputusan penting yang harus dilakukan oleh seorang manajer (keuangan) dalam kaitannya dengan kelangsungan operasi perusahaan atau keputusan struktur modal karena pada dasarnya pendanaan perusahaan berasal dari dua sumber internal yang diperoleh dari operasi perusahaan dan sumber eksternal melalui pinjaman atau menjual saham (Tendi Haruman, 2008: 153). Keputusan pendanaan merupakan keputusan mengenai sumber dana yang akan digunakan oleh perusahaan. Sumber dana terbagi dua yaitu sumber dana internal dan sumber dana eksternal. Sumber dana eksternal yang digunakan oleh perusahaan adalah hutang dan modal sendiri. Untuk menentukan komposisi pendanaan yang optimal yang nantinya dapat mempengaruhi nilai perusahaan seorang manajer haruslah mampu untuk mempertimbangkan komposisi antara penggunaan hutang dengan modal sendiri. Keputusan 
pendanaan yang digunakan dalam penelitian ini merupakan rasio solvabilitas yaituDebt to Equity Ratio. Debt to Equity Ratio (DER) adalah rasio ini mambarkan perbandingan utang dan ekuitas dalam pendanaan perusahaan dan menunjukkan kemampuan modal sendiri perusahaan tersebut untuk memenuhi kewajibannya (Sawir, 2005: 13).

Menurut Modigliani dan Miller dalam Tendi Haruman (2008: 49) menyatakan bahwa pendanaan dapat meningkatkan nilai perusahaan.Apabila pendanaan didanai melalui hutang, peningkatan tersebut terjadi akibat dari efek tax deductible. Artinya, perusahaan yang memiliki hutang akan membayar bunga pinjaman yang dapat mengurangi penghasilan kena pajak, yang dapat memberi manfaat bagi pemegang saham. Selain itu, penggunaan dana eksternal akan menambah pendapatan perusahaan yang nantinya akan digunakan untuk kegiatan investasi yang menguntungkan bagi perusahaan. Keputusan pendanaan merupakan salah satu keputusan yang paling kritis dan pekerjaan yang menantang untuk manajer keuangan, hal itu disebabkan karena keputusan ini memiliki dampak langsung pada kinerja keuangan dan struktur modal dari perusahaan (Kumar et al., 2012). Miller dalam Rury Setiani (2012) menyimpulkan bahwa penggunaan hutang (leverage) akan meningkatkan nilai perusahaan karena biaya bunga hutang dalah biaya yang mengurangi pembayaran pajak. Sedangkan menurut teori trade off menyatakan bahwa penggunaan hutang akan meningkatkan nilai perusahaan tapi hanya sampai titik tertentu. Setelah titik tersebut, penggunaan hutang justru kan menurunkan nilai perusahaan karena kenaikan keuntungan dari penggunaan hutang tidak sebanding dengan kenaikan biaya financial distress. Moradi et al. (2012) serta Wijaya dkk. (2010) menemukan financial leverage berpengaruh positif terhadap nilai perusahaan. Berdasarkan tinjauan teori dan penelitian terdahulu tersebut maka dapat dirumuskan hipotesis sebagai berikut: $\mathrm{H} 2$ : Keputusan pendanaan berpengaruh negatif dan signifikan terhadap nilai perusahaan manufaktur sektor food and beverages di Bursa Efek Indonesia periode $2011-2014$. 


\section{Pengaruh kebijakan dividen terhadap nilai perusahaan}

Dividen adalah pembagian laba perusahaan kepada para pemegang saham yang besarnya sebanding dengan jumlah lembar saham yang dimiliki (Zaki Baridwan, 2004: 434). Sedangkan pengertian dividen menurut Bambang Riyanto (2001: 265) dividen adalah aliran kas yang dibayarkan kepada para pemegang saham atau equity investors. Capital gain adalah keuntungan yang diperoleh dari penjualan aktiva tetap atau selisih harga jual dan harga beli surat berharga (Agus Sartono, 2011: 483). Kebijakan dividen adalah ketetapan pihak manajemen perusahaan dalam membagi keuntungan perusahaan kepada pemegang saham dengan tetap memperhatikan alokasi laba ditahan sebagai dana internal untuk melakukan reinvestasi (Nahdiroh, 2013). Apabila perusahaan memilih untuk membagikan laba sebagai dividen, maka akan mengurangi laba yang ditahan dan selanjutnya mengurangi total sumber dana intern atau internal financing. Sebaliknya jika perusahaan memilih untuk menahan laba yang diperoleh, maka kemampuan pembentukan dana intern akan besar (Agus Sartono, 2011: 281).

Kebijakan dividen dapat dilihat dari nilai Dividen Payout Ratio (DPR) yang merupakan bagian dari laba bersih perusahaan yang dibagikan sebagai dividen. Besarnya dividen yang dibagikan kepada para pemegang saham akan menjadi daya tarik bagi pemegang saham karena sebagian investor cenderung lebih menyukai dividen dibandingkan dengan capital gain karena dividen bersifat lebih pasti. Banyaknya investor yang berinvestasi di perusahaan tersebut dapat menyebabkan meningkatnya harga saham sehingga dengan meningkatnya harga saham akan meningkatkan nilai perusahaan itu sendiri. Jadi kebijakan dividen yang ditetapkan oleh perusahaan dapat mempengaruhi nilai perusahaan. Patra (2008) dan Ardestani et al. (2013), Wijaya, dkk (2010) menemukan kebijakan dividen berpengaruh terhadap keputusan pendanaan. Berdasarkan tinjauan teori dan penelitian terdahulu tersebut maka dapat dirumuskan hipotesis sebagai berikut: H3 : Kebijakan dividen berpengaruh positif dan signifikan terhadap nilai perusahaan manufaktur sektor food and beverages di Bursa Efek Indonesia periode $2011-2014$. 


\section{Kerangka Pemikiran}

Kerangka pemikiran digunakan untuk mempermudah arah dalam penelitian untuk mencapai tujuan penelitian yang diinginakan. Kerangka pemikiran dalam penelitian ini dapat digambarkan sebagai berikut:

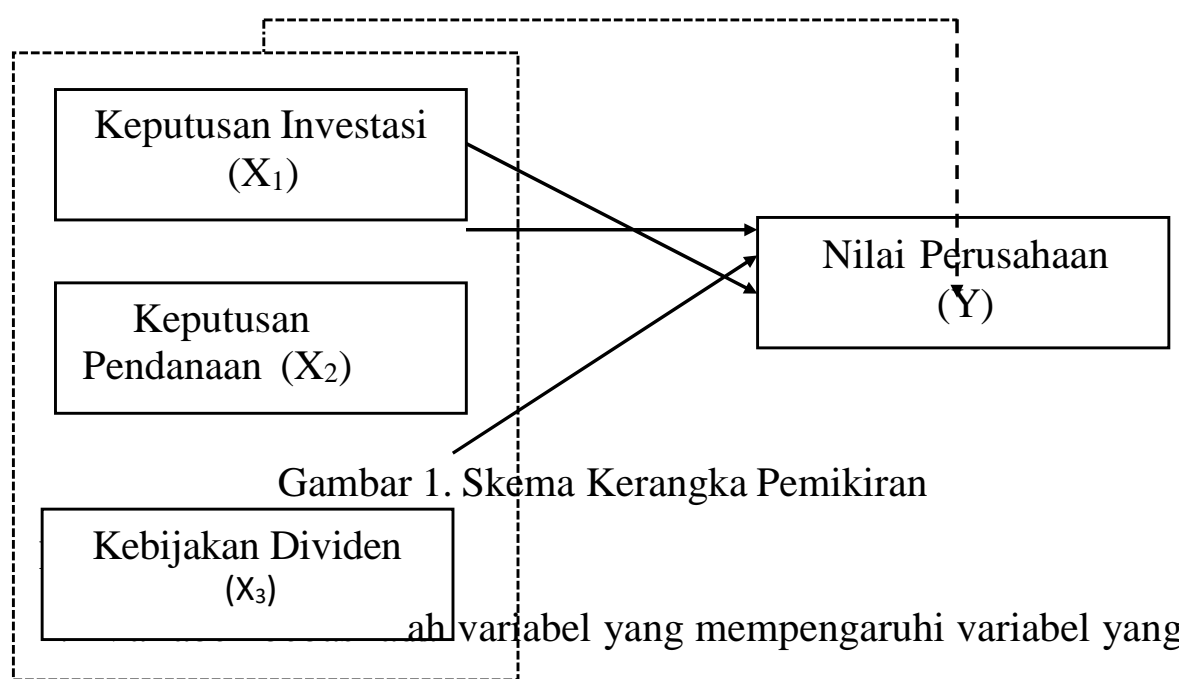

lain. Variabel bebas dalam penelitian ini adalah : Keputusan Investasi $\left(\mathrm{X}_{1}\right)$, Keputusan Pendanaan $\left(\mathrm{X}_{2}\right)$ dan Kebijakan Dividen $\left(\mathrm{X}_{3}\right)$

2. Variabel terikat adalah variabel yang dipengaruhi oleh variabel yang lain. Variabel terikat dalam penelitian ini adalah nilai perusahaan.

\section{Metode Penelitian}

Jenis penelitian ini adalah penelitian deskriptif kuantitatif dengan metode studi kasus.Penelitian ini dilakukan di perusahaan manufaktur sektor food and beverages yang terdaftar di Bursa Efek Indonesia sebanyak 17 perusahaan. Teknik sampel dalam penelitian ini menggunakan purposive sampling. Purposive sampling merupakan pemilihan sampel atas dasar kesesuaian antara sampel dengan kriteria pemilihan tertentu.Kriteria yang digunakan dalam penelitian ini adalah perusahaan manufaktur sektor food and beverages yang terdaftar di Bursa Efek Indonesia dan secara rutin mempublikasikan laporan keuangannya periode 2011-2014. Sumber data menggunakan data sekunder yang bersumber dari Indonesian Capital Market Directory dan juga dari website www.idx.co.id. Teknik pengumpulan data menggunakan dokumentasi dan studi pustaka. Teknik analisis data yang digunakan adalah regresi linear berganda. 


\section{Pembahasan}

\section{Statistik Deskriptif}

Populasi dalam penelitian ini adalah perusahaan manufaktur sektor food and beverages yang terdaftar di Bursa Efek Indonesia dan sampel dalam penelitian ini adalah perusahaan sektor perusahaan manufaktur sektor food and beverages yang terdaftar di Bursa Efek Indonesia yang mempublikasikan laporan keuangannya periode 2011-2014 sehingga diperoleh total data awal sebanyak $(17 \times 4)=68$ data Berikut adalah deskriptif variabel yang digunakan dalam penelitian ini

Tabel 1.

\section{Statistik Deskriptif Variabel} Penelitian

\begin{tabular}{lllllc}
\hline Variabel & $\mathrm{N}$ & Minimum & Maximum & Mean & Std. Deviation \\
\hline PER & 68 & 2,93 & 230,16 & 30,81 & 38,14 \\
DER & 68 & 0,22 & 3,03 & 1,01 & 0,48 \\
DPR & 68 & 0,68 & 100,00 & 23,18 & 19,96 \\
PBV & 68 & 0,37 & 48,67 & 5,09 & 8,45 \\
\hline
\end{tabular}

a. Hasil penelitian menunjukkan bahwa variabel keputusan investasi (PER) memiliki nilai minimal 2,93, maksimal 230,16, rata-rata 30,81 , dengan standar deviasi 38,14

b. Hasil penelitian menunjukkan bahwa variabel keputusan pendanaan (DER)memiliki nilai minimal 0,22, maksimal 3,03, rata-rata 1,01, dengan standar deviasi 0,48 .

c. Hasil penelitian menunjukkan bahwa variabel kebijakan dividen (DPR) memiliki nilai minimal 0,68 , maksimal 100,00 rata-rata 23,18, denganstandar deviasi 19,96

d. Hasil penelitian menunjukkan bahwa variabel nilai perusahaan (PBV) memiliki nilai minimal 0,37, maksimal 48,67 rata-rata 5,09, dengan standar deviasi 8,45. 
1. Regresi Linear Berganda

Analisis regresi linier berganda digunakan untuk mengetahui pengaruh variabel bebas (keputusan investasi, keputusan pendanaan, kebijakan dividen) terhadap variabel terikat (nilai perusahaan). Hasil Persamaan regresi bergandadapat dilihat pada tabel sebagai berikut :

Tabel 2.

Hasil Uji Regresi Linier Berganda

\begin{tabular}{llll}
\hline Model & \multicolumn{2}{l}{ Unstandardized Coefficients } & Standardized \\
\hline Coefficients & B & Std. Error & Beta \\
\hline (Constant) & -1.492 & .661 & \\
Ln_PER & .406 & .161 & .283 \\
Ln_DER & .060 & .186 & .036 \\
Ln_DPR & .445 & .131 & .382 \\
\hline
\end{tabular}

Hasil persamaan regresi linear berganda adalah sebagai berikut: $Y=-1,492+0,406 X_{1}+0,060 X_{2}+0,445 X_{3}+$ e

Interpretasi persamaan regresi tersebut adalah sebagai berikut : $\mathrm{a}=$ Konstanta adalah sebesar -1,492, artinya apabila variabel keputusan investasi, keputusan pendanaan dan kebijakan dividen dianggap tetap, maka nilai perusahaan adalah negatif.

$b_{1}=$ Koefisien variabel periode keputusan investasi (PER) sebesar $0,406\left(\mathrm{X}_{1}\right)$, artinya apabila price earning ratio meningkat sebesar satu-satuan, maka nilai perusahaan akan mengalami peningkatan sebesar 0,406 dengan asumsi variabel keputusan pendanaan dan kebijakan dividen dianggap konstan.

$b_{2}=$ Koefisien variabel keputusan pendanaan (DER) sebesar 0,060 (X2), artinya apabila debt to equity ratio meningkat sebesar satu-satuan, maka nilai perusahaan akan mengalami peningkatan sebesar 0,060 dengan asumsi variabel keputusan investasi dan kebijakan dividen dianggap konstan. 
$\mathrm{b}_{3}=$ Koefisien variabel kebijakan dividen (DPR) sebesar 0,445 $\left(\mathrm{X}_{3}\right)$, artinya apabila dividend payout ratio meningkat sebesar satu-satuan, maka nilai perusahaan akan mengalami peningkatan sebesar 0,445 dengan asumsi variabel keputusan investasi dan keputusan pendanaan dianggap konstan.

2. $\mathrm{Uji} \mathrm{F}$

Hasil uji $\mathrm{F}$ diperoleh nilai $\mathrm{F}$ hitung 5,371 dengan $p$ value $0,002<0,05$ berarti terdapat pengaruh variabel bebas (keputusan investasi, keputusan pendanaan dan kebijakan dividen secara bersama-sama terhadap variabel terikat (nilai perusahaan) pada perusahaan manufaktur sektor food and beverages yang terdaftar di Bursa Efek Indonesia.

3. Uji t

a. Pengaruh keputusan investasi terhadap nilai perusahaan

Hasil penelitian diperoleh nilai t hitung 2,513 dengan $p$ value 0,003

$<0,05$ sehingga keputusan investasi berpengaruh positif dan signifikan terhadap nilai perusahaan pada perusahaan manufaktur sektor food and beverage yang terdaftar di Butsa Efek Indonesia.

b. Pengaruh keputusan pendanaan terhadap nilai perusahaan Hasil penelitian diperoleh nilai t hitung 0,323 dengan $p$ value 0,748

$>0,05$ sehingga keputusan pendanaan berpengaruh positif tetapi tidak signifikan terhadap nilai perusahaan pada perusahaan manufaktur sektor food and beverages yang terdaftar di Butsa Efek Indonesia

c. Pengaruh kebijakan dividen terhadap nilai perusahaan

Hasil penelitian diperoleh nilai t hitung 3,395 dengan $p$ value 0,001

$<0,05$ sehingga kebijakan dividen berpengaruh positif dan signifikan terhadap nilai perusahaan pada perusahaan manufaktur sektor food and beverages yang terdaftar di Butsa Efek Indonesia

\section{Koefisien Determinasi}

Hasil koefisien determinasi (Adjusted $R^{2}$ ) sebesar 0,164 artinya besarnya sumbangan atau pengaruh variabel keputusan investasi, keputusan pendanaan dan kebijakan dividen terhadap nilai perusahaan sebesar $16,4 \%$, sedangkan 
sisanya sebesar 83,6\% dipengaruhi oleh variabel lain yang tidak diteliti, misalnya adalah harga saham dan ukuran perusahan.

\section{Pengaruh keputusan investasi terhadap nilai perusahaan}

Hasil penelitian menunjukkan bahwa keputusan investasi berpengaruh positif dan signifikan terhadap nilai perusahaan. Hasil ini mendukung penelitian Yulia Efni, dkk (2012) Keputusan investasi berpengaruh terhadap nilai perusahaan. Lihan Rini Puspo Wijaya, dkk (2010) bahwa keputusan investasi berpengaruh positif terhadap nilai perusahaan. Ratna Ika Puspitaningtyas (2014) keputusan investasi berpengaruh positif dan signifikan terhadap nilai perusahaan. Investasi merupakan tindakan untuk menanamkan dana yang dimiliki saat ini ke dalam bentuk aktiva lancar maupun aktiva tetap dengan harapan untuk memperoleh keuntungan di masa yang akan datang (Salim dan Moeljadi, 2001: 110). Kegiatan investasi yang dilakukan oleh perusahaan diharapkan memberikan laba yang optimal yang digunakan kembali untuk kegiatan investasi atau dibagikan kepada pemegang saham dalam bentuk dividen.

Tri Wahyuni, dkk (2013) menyatakan bahwa apabila investasi perusahaan bagus maka akan berpengaruh pada kinerja perusahaan dan hal inipun akan direspon positif pada investor dengan membeli saham perusahaan tersebut sehingga harga saham akan naik. PER yang semakin positif menandakan bahwa investasi perusahaan semakin bagus. Implikasi dalam penelitian ini dalam upaya meningkatkan nilai perusahaan melalui keputusan investasi (price earning ratio) maka dalam upaya meningkatkan minat investor untuk menginvestasikan dananya maka perusahaan food and beverages harus mampu menghasilkan laba optimal dengan cara perluasan produksi dengan pengenalan produk baru atau perluasan produk lama, penggantian peralatan atau gedung, penelitian dan pengembangan, serta eksplorasi, karena investasi yang dilakukan perusahaan tersebut dapat memberikan sinyal positif tentang pertumbuhan pendapatan perusahaan di masa yang akan datang. 


\section{Pengaruh Keputusan Pendanaan Terhadap Nilai Perusahaan}

Hasil penelitian menunjukkan bahwa keputusan pendanaan berpengaruh positif tetapi tidak signifikan terhadap nilai perusahaan. Hasil penelitian ini sesuai dengan hasil penelitian yang dilakukan oleh Mardiyati, Ahmad, dan Putri (2012) dan Rakhimsyah dan Gunawan (2011), namun bertentangan dengan hasil penelitian Moradi et al. (2012) serta Wijaya dkk. (2010) menemukan financial leverage berpengaruh positif terhadap nilai perusahaan.

Keputusan pendanaan merupakan salah satu keputusan yang paling kritis dan pekerjaan yang menantang untuk manajer keuangan, hal itu disebabkan karena keputusan ini memiliki dampak langsung pada kinerja keuangan dan struktur modal dari perusahaan (Kumar et al., 2012). Miller dalam Rury Setiani (2012) menyimpulkan bahwa penggunaan hutang (leverage) akan meningkatkan nilai perusahaan karena biaya bunga hutang dalah biaya yang mengurangi pembayaran pajak. Sedangkan menurut teori trade off menyatakan bahwa penggunaan hutang akan meningkatkan nilai perusahaan tapi hanya sampai titik tertentu. Setelah titik tersebut, penggunaan hutang justru kan menurunkan nilai perusahaan karena kenaikan keuntungan dari penggunaan hutang tidak sebanding dengan kenaikan biaya financial distress.

Menurut Rakhimsyah dan Gunawan (2011) keputusan pendanaan tidak berpengaruh terhadap nilai perusahaan karena hutang merupakan salah satu sumber pembiayaan yang berisiko tinggi. Penggunaan hutang yang tinggi akan menyebabkan timbulnya kebangkrutan, biaya keagenan, beban bunga yang semakin besar, dan sebagainya. Implikasi dalam penelitian ini dalam upaya meningkatkan nilai perusahaan melalui keputusan pendanaan (debt to equity ratio) yaitu perusahaan food and beverage harus merencanakan untuk mengambil keputusan pendanaan yang menggunakan pendanaan melalui ekuitas lebih banyak daripada pendanaan melalui hutang karena dengan menggunakan pendanaan melalui ekuitas lebih banyak dapat meningkatkan nilai perusahaan. Implikasi bagi investor adalah investor akan menginvestasikan dananya pada perusahaan yang memiliki proporsi hutang yang kecil dalam struktur modalnya karena semakin 
kecil proporsi hutang perusahaan, maka risiko atas tidak terlunasinya hutang perusahaan juga semakin kecil. Selain itu, investor akan menerima pendapatan setelah pajak yang semakin besar apabila proporsi hutang perusahaan semakin kecil.

\section{Pengaruh Kebijakan Dividen Terhadap Nilai Perusahaan}

Hasil penelitian menunjukkan bahwa kebijakan dividen berpengaruh positif dan signifikan terhadap nilai perusahaan. Hasil penelitian ini mendukung penelitian Patra (2008) dan Ardestani et al. (2013), Wijaya, dkk (2010) menemukan kebijakan dividen berpengaruh terhadap keputusan pendanaan. Wijaya, dkk (2010) menyatakan bahwa kebijakan dividen tersebut adalah membagikan laba yang diperoleh perusahaan kepada pemegang saham dalam bentuk dividen. Implikasi bagi perusahaan adalah perusahaan harus merencanakan untuk mengambil kebijakan dividen yang membagikan labanya kepada pemegang saham dalam bentuk dividen daripada menahan labanya dalam bentuk capital gain karena dengan membagikan labanya kepada pemegang saham dalam bentuk dividen dapat meningkatkan nilai perusahaan. Konsekuensi apabila perusahaan membagikan laba kepada pemegang saham dalam bentuk dividen, maka laba ditahan akan berkurang, sehingga perusahaan harus mengeluarkan saham baru untuk mendanai kegiatannya. Implikasi bagi investor adalah investor akan menginvestasikan dananya pada perusahaan yang membagikan labanya dalam bentuk dividen secara konsisten. Investor juga akan menginvestasikan dananya pada perusahaan yang membagikan dividen dalam jumlah yang besar dengan konsekuensi investor harus membayar pajak yang tinggi atas dividen yang diperoleh tersebut.

\section{Kesimpulan}

Berdasarkan pembahasan dapat disimpulkan bahwa kebijakan dividen berpengaruh positif dan signifikan terhadap nilai perusahaan manufaktur sektor food and beverages, sehingga sebaiknya calon investor atau penanam modal 
dalam melakukan investasi memperhatikan faktor keputusan investasi, keputusan pendanaan dan kebijakan dividen tersebut sebagai dasar pengambilan keputusan untuk melakukan investasi atau tidak. Beberapa implikasi kebijakan dalam penelitian ini antara lain adalah sebagai berikut:

1. Dalam upaya meningkatkan minat investor untuk menginvestasikan dananya maka perusahaan harus mampu menghasilkan laba optimal dengan cara perluasan produksi dengan pengenalan produk baru atau perluasan produk lama, penggantian peralatan atau gedung, penelitian dan pengembangan, serta eksplorasi, karena investasi yang dilakukan perusahaan tersebut dapat memberikan sinyal positif tentang pertumbuhan pendapatan perusahaan di masa yang akan datang.

2. Perusahaan harus merencanakan untuk mengambil keputusan pendanaan yang menggunakan pendanaan melalui ekuitas lebih banyak daripada pendanaan melalui hutang karena dengan menggunakan pendanaan melalui ekuitas lebih banyak dapat meningkatkan nilai perusahaan. Implikasi bagi investor adalah investor akan menginvestasikan dananya pada perusahaan yang memiliki proporsi hutang yang kecil dalam struktur modalnya karena semakin kecil proporsi hutang perusahaan, maka risiko atas tidak terlunasinya hutang perusahaan juga semakin kecil. Selain itu, investor akan menerima pendapatan setelah pajak yang semakin besar apabila proporsi hutang perusahaan semakin kecil.

3. Investor akan menginvestasikan dananya pada perusahaan yang membagikan labanya dalam bentuk dividen secara konsisten. Investor juga akan menginvestasikan dananya pada perusahaan yang membagikan dividen dalam jumlah yang besar dengan konsekuensi investor harus membayar pajak yang tinggi atas dividen yang diperoleh tersebut.

\section{Daftar Pustaka}

Efni, Yulia., Hadiwidjojo, D., Salim, U., dan Rahayu, M. 2011. Keputusan Investasi, Keputusan Pendanaan, dan Kebijakan Dividen:Pengaruhnya 
Terhadap Nilai Perusahaan (Studi Pada Sektor Properti dan Real Eastate diBursa Efek Indonesia). Jurnal Aplikasi Manajemen, 10 (1) : h : 128-141.

Fakhrudin, M dan Harjito, D. A. 2006. Hubungan Kebijakan Hutang, Insider ownership dan Kebijakan Dividen dalam Mekanisme Pengawasan Masalah Agensi di Indonesia. Jurnal Akuntansi dan Auditing Indonesia , 10 (2), 161-182.

Fenandar, Ganny I., Raharja, S. 2012. Pengaruh Keputusan Investasi, Keputusan Pendanaan, dan Kebijakan Dividen terhadap Nilai Perusahaan. Jurnal Akuntansi, 1 (2) : h: 1-10.

Haruman, Tendi. 2008. Pengaruh Struktur Kepemilikan Terhadap Keputusan Keuangan dan Nilai Perusahaan: Studi Pada Perusahaan Manufaktur di PT. Bursa Efek Indonesia. Makalah Simposium Nasional Akuntansi 11 . Pontianak.

Hermuningsih, Sri dan Wardani, Dewi Kusuma. 2009. Faktor-faktor yang Mempengaruhi Nilai Perusahaan Pada Perusahaan yang Terdaftar di Bursa Efek Malaysia dan Bursa Efek Indonesia, Jurnal Siasat Bisnis, Vol. 13 No. 2; 173-183

Honarbakhsh, S., Birjandi, H., and Birjandi M. 2013. The Effects of Dividend Policy on Market Value on Companies Listed In Tehran Stock Exchange. International Review of Management and Business Research, 1(1): pp: 65-75.

Kumar, S., Anjum, B., and Nayyar, S. 2012. Financing Decisions : Studi of Pharmaceutical Companies of India. International Journal of Marketing, Financial Services \& Management Research, 1(1): pp : 14-28.

Lestari, Indri F., Taufik, T., dan Yusralaini.2012. Pengaruh Kebijakan Dividen, Kebijakan Hutang, Keputusan Investasi, dan Kepemilikan Insider terhadap Nilai Perusahaan (Studi Empiris Pada Seluruh Perusahaan Manufaktur yang Terdaftar di Bursa Efek Indonesia 2008-2011.h: 1-15.

Moradi, Nassim S., Aldin, Mahmood M., Heyrani, F., and Iranmhad, M. 2012. The Effect of Corporate Governance, Corporate Financing Decision and Ownership Structure on Firm Performance: A Panel Data Approach from Tehran Stock Exchange. International Journal of Economics and Finance, 4 (6) : pp: 86-93

Murekefu, TM., 2012, The Relationship Between Dividend Payout And Firm Performance: A Study Of Listed Companies In Kenya. European Scientific Journal, Vol. 8, No.9 pp 199-215. 
Nadhiroh, U. 2013. Studi Empiris Keputusan-Keputusan Dividen, Investasi, dan Pendanaan Eksternal pada Perusahaan-Perusahaan Indonesia yang Go Public di Bursa Efek Indonesia. Jurnal Otonomi, 13 (1) : h: 91-104.

Pujiati, Diyah dan Widanar, Erman, 2009, Pengaruh Struktur Kepemilikan Terhadap Nilai Perusahaan Keputusan Keuangan Sebagai Variabel Intervening. Jurnal Ekonomi Bisnis \& Akuntansi Ventura, Volume 12 No 1 Hal 71-86

Puspitaningtyas, Ratna Ika. 2014. Pengaruh Keputusan Investasi, Keputusan Pendanaan, Kebijakan Dividen, dan Tingkat Suku Bunga Terhadap Nilai Perusahaan, Jurnal Riset Mahasiswa Akuntansi, Vol 2 No 14.

Shubiri, Faris N., Taleb, G., and Zoued, N. 2012. The Relationship between Ownership Structure and Dividend Policy: An Empirical Investigation. Review of International Comparative 644 Management, 13(4): pp: 644657. 